\title{
Fibroblast Growth Factor 13
}

National Cancer Institute

\section{Source}

National Cancer Institute. Fibroblast Growth Factor 13. NCI Thesaurus. Code 1118515.

Fibroblast growth factor 13 (245 aa, $28 \mathrm{kDa}$ ) is encoded by the human FGF13 gene. This protein plays a role in the regulation of both the development of the nervous system and microtubule polymerization. 